\title{
Tell me your Name and your Business; or, Some Considerations upon the Purposeful Naming of Children
}

\author{
WILBUR G. GAFFNEY
}

\begin{abstract}
"Must a name mean something ?" Alice asked doubtfully. "Of course it must," Humpty Dumpty said ... "My name means the shape I am ... With a name like yours, you might be any shape, almost."
\end{abstract}

- Through the Looking-Glass.

\begin{abstract}
M OST PEOPLE, perhaps, simply take their names for granted, as they take their metabolism, their noses, and their hair coloring. Certainly I spent some 40 years with my name, without giving it a second thought, and yet another 12 before I assembled the scattered pieces of what turned out to be an interesting little puzzle. My first name was that of a revered grandfather, carried from its Connecticut source out across the wide Missouri; my middle name reflected some literary memory or admiration; and my family name was merely that of a numerous tribe who had fled the Emerald Isle in the wake of the Potato Famine. I got interested in words and place-names by studying under Louise Pound and, by indirection, H. L. Mencken; but it took another 30 years and membership in the American Name Society to whip into shape a tentative theory about personal naming - a theory with which, I suggest, an individualistic nation may confidently face the present and future population explosions.

The naming of children in the United States has always been more a matter of personal taste than of either legal prescription or deep family tradition. The influence of individual parental whim is fairly ancient: our first two Anglo-Saxon children were Virginia Dare (born on Roanoke Island in 1587) and Peregrine, i.e., "Pilgrim," White (born aboard the Mayflower, just off Cape Cod, on November 20, 1620). Names of children have, for some 300 years, been commonly chosen (1) for euphony, (2) to please some favorite relative, or (3) merely to fall in with changing fashions in naming. Such a process represents, if not the will, at least the
\end{abstract}


collective whim, of a democratic people. Such a process presumably satisfies the parents, may perhaps satisfy the children. But it takes no thought for the future. Consider: what would you wish your child to be?

Psychologists have already dipped a cautious toe or two into this pond. At least one has produced a learned and careful examination of the ways in which people write their names. (See A. A. Hartman, "Name Styles in Relation to Personality," Journal of General Psychology, October 1958, pp. 289-294.) But this, of course, is merely an ex post facto study of the probability that the forms of name that people use are influenced by personality, occupation, pose (Weltangesicht), and similar factors.

My theory takes a diametrically opposite approach. My own extended research, aided by numerous willing correspondents, into American personal names makes it seem more than merely probable that names can influence character, personality, and occupation; and that (therefore) a parent can determine, or at any rate help to determine, his child's career by the kind of name he bestows. Personal choice need not be ruled out, as under the sometime French custom of requiring children to be christened only with names taken from the calendar of saints, or a recent (1968) Italian ruling against "offbeat" names. (Such restrictions lead only to the kind of revolt that led one famous pre-beatnik to rechristen himself Anacharsis Clootz, and a Stewart Edward White cowboy to adopt the resounding name of Tuscarora Maxillary.) Even should a parent follow closely the precepts hereafter set forth, an infinite - perhaps even all-too-infinite - range of names remains open. In the present state of my theory, we are concerned only with categories of names; but, within the categories I shall here present, I suggest that the distinctions may have more than superficial validity.

Some years ago, while defending my country against its enemies in a plasterboard-cum-pliofilm foxhole, I was given the task of checking endless rosters of officers and enlisted men. (The latter term seemed, to my Pentagon-based betters, a semantic improvement over "conscripts.") While engaged in this dullish task, I had no reason to suspect that I was moving, however slowly, toward a perhaps revolutionary discovery. The job seemed merely dull; and it was only to lighten the surrounding tedium - of which there was, as the poet Helen Hull once put it, "plenty, and more than plenty" - that I took to tabulating the names which became the basis of what I am now ready to announce to the world as Gaffney's First Law of Nomenclature.

This Law may be tentatively stated: "Your career is determined by your character; and your character, in turn, is determined, perhaps unalterably, by the name under which you grew to adulthood." Or, to put it more simply, borrowing a phrase from Gayelord Hauser: "You are what your name has made you." 
The Army was quite strict about having all of a man's names down on paper, and about calling him by the first of his given names, regardless of his own usage or preference. There was no appeal from this custom. If, to avoid confusions because his father's name was Herbert, a boy had spent 20 years known as H. Theodore Grimsby, no matter; to the Army, he was Herbert T. Grimsby. Even a missing middle initial had to be accounted for. If parents had so far departed from old 100 per cent American custom as not to have bestowed a middle name, the Army proceeded to brand the eccentric one as having "No Middle Initial." For the records, he became forever, up to and including his VA burial in Arlington, "Joseph (NMI) Smith." Further, the rule was explicit that names $h a d$ to be baptismal names, without variation or exception.

Rosters of enlisted men, therefore, made only average and unexciting reading, except for the occasional appearance of mildly oddish names such as Pinky, Pearl, Rosy, June, or Isar (= Isaiah). (The provenance of similar names has been well and fully discussed by Thomas Pyles, "Onomastic Individualism in Oklahoma," American Speech, December 1947, pp. 257-264, and "Bible Belt Onomastics," Names, June 1959, pp. 84100.) But my eye was quickly caught by the fact that rosters of officers showed a different pattern. In numbers far exceeding such instances among enlisted men, who presumably represented a fair cross-section of American males, officers kept turning up with such names as Jack, Tom, Harry, Bud, Bob, and Sam. The rigidity of the Army's rules made it absolutely clear that these were indeed christened names rather than just personal or family shortenings.

By themselves, these observations seemed nothing more than mildly amusing coincidences. Although I tentatively tried to evolve some reason, I found none. However, not long after noting this first set of facts, I ran into a second set, which seemed to offer some logical basis for, as well as some confirmation of, the first facts. When I undertook the routine task of compiling thumbnail biographies of several thousand officers - for the practical, even if then still "Confidential," reason that Public Relations would need these for the home-town papers when the name-bearers got killed in action or vanished over Düsseldorf - a pattern began to appear. Almost without exception, the officers with these terse forenames were not Regulars, professional products of West Point. Most had either (a) enlisted in the peacetime Army and come up through the ranks, or $(b)$ been drafted and come up via the Officer Candidate Schools.

These observations led to a generalization: boys known all through their lives by masculine-sounding, or outdoorsman-type, names had perhaps led relatively extroverted lives, had perhaps spent more time in hunting and fishing and fighting than in reading books. They might, therefore, be assumed to have possessed more stamina for the very real 
rigors of the Officer Schools; they might also have developed, fairly early in life, qualities of physical leadership.

Axiom I, therefore, became: 'Men with extroverted, or 'he-man,' names tend to become leaders in extroverted pursuits, such as the military life."

This loose generalization provided conversation and provoked some edifying arguments (especially with introverted types who had been washed out of officer training). But the larger idea might have been lost to posterity if I had not later, after a 20-year lapse, renewed my erstwhile contact with the Sacred Groves and, thus, with lists of academic persons.

One glance at a college catalogue led me to wonder whether my Axiom had a converse which would also be true - viz., that introverted, or non-"he-man," names might almost automatically turn their possessors to mental or reflective pursuits.

To conduct this phase of the investigation on a more serious plane than its predecessor, which had originated merely as a half (or quarter) intellectual game for dull afternoons, it was necessary to set up certain criteria :

1. No name was to be considered merely because of some odd sound or connotation. Frank Sullivan, Stanley Walker, and others of us have from time to time collected odd names just for fun; but this was now an investigation, not a game.

2. Foreign names, when recognizable as such, had to be arbitrarily excluded for lack of information for comparisons. Names such as Konni Zilliacus, A. Toxen Worm, Arpad Philomene Arbogast, and Fice Mork, Jr., much as they might delight Frank Sullivan or S. J. Perelman, might prove, if one had access to foreign directories, to be as common in their home nations as John Smith is supposed to be in Anglo-Saxonia.

3. Only given names could be included in the consideration of what constituted unusual nomenclature, since family names are accidental. However, the combination of an unusual given name with either a markedly unusual or a too-usual family name - for example, Guernsey Jones - might be worth consideration.

4. Women's names had, in general, to be excluded because of the impossibility, in many academic lists, of determining whether or not a middle name (plain or fancy) was a baptismal or a maiden name. Where no such doubt existed, as with obvious maiden ladies with $\mathrm{Ph}$. D.'s dating back to, for example, 1912, female names were of course acceptable evidence.

5. Faculty listings from Negro colleges had to be excluded, because of the long-familiar tendency (nowadays visibly diminishing) toward a certain exuberance or floridity of nomenclature. For very similar reasons, 
it was necessary to filter carefully names listed at Southern colleges attended by or professored by Deep-South Anglo-Saxons. (See Thomas Pyles, op. cit., supra.)

After setting up these basic exclusions, the next step was to find a method of selecting materials for study. Baptismal names, as H. L. Mencken long ago pointed out, tend to run in generation-cycles; male names are influenced by politicos, and female names by feminine motionpicture performers. Thus it was necessary to be well aware of the foibles of particular parent-generations. Further, personal names frequently represent regional idiosyncrasies, particularly in New England and the South. To avoid these potential fallacies, I selected college catalogues from widely scattered sections of the United States and covering, at random, a period of approximately 40 years.

The findings, which developed with surprising promptness, were gratifying. In a one-generation-past catalogue of my present college, I found a striking collection of resounding names, as "individual" and as far from the Jack, Tom, and Ed type of names as could be wished. I quote here only a few, chosen as the most luscious: Grove Ettinger Barber, Theodore Tunison Bullock, Rizpah Anna Douglas, Fred Morrow Fling, Lucius Adelno Sherman, Constance Miriam Syford, Sherlock Bronson Gass, Artemus Isaac McKinnon, Enger Kathryn Lenore Robertson, Rodney Waldo Bliss, Coral Edison Demaray, Martha Theodora Fiegenbaum, Prosser Hall Frye, and Melanchthon B. Posson (20 intervening years have not revealed what the $B$ stood for). One must also include Theos Jefferson Thompson, whose simplified signature, "T. J.," fooled three generations of students and, sometimes, colleagues.

College and university catalogues from other states and other areas showed, percentagewise, almost no variation from or diminution of this general richness of polyphlosboian nomenclature: a wealth of names that were, if not totally unique, at least non-ordinary, non-pedestrian. A few more or less random specimens must suffice:

Guy Redvers Lyle, Florinell Francis Morton, Fadra Holmes Wilson St. John Poindexter Chilton, Lilburne Michelson Daspit, Juanita Francine Merritt, Elbert Nevius Sebring Thompson, Homer Vergil Cherrington, Millington Farwell Carpenter, Hambleton Tapp, Bethania Smith, Azile May Wofford, Tyus Butler, Uriah Harold Davenport, Wymberly Wormsloe de Renne, Linville Laurentine Hendren, Wooten Taylor Sumerford, Duchess Williams Taylor, Comer Whitehead, Lysle Warwick Croft, Lehre Livingston Dantzler, Fordyce Ely, Statie Estelle Erikson, Sadocie Connellee Jones, and Berthus Boston McInteer. And, to move from the strictly academic to the "literary" world, one might add the familiar names of Vermont Connecticut Royster, editor of the Wall Street Journal, and Merryle Stanley Rukeyser, a syndicated financial columnist. 
A tentative assumption to explain the preponderance of such resonant names among academic or literary persons might be that families giving their children impressive names might be independent minds in their communities, which fact, in turn, might indicate the presence of books and at least a parental disposition toward learning. I purposely use the term impressive here to differentiate this type of names from such names as often seem, to the outsider, merely absurd or eccentric - common in the South, in New England, in upstate New York (a province by itself), the "typical" Midwest, and California (a province, in partibus infidelium, of the Deep South).

We thus arrive at Axiom II: "Children with unusual names tend to become bookish early in life, and (perhaps as a direct consequence) frequently end up as professors."

Now, if there is not some soundness to this theory that extroverted names produce Army officers and men of action, and that introverted names produce professors and other "mental" types, we need some explanation for the curious fact that faculty lists - which tend to prefer full names - include athletic coaches with such names as Lew Bostic, Don Seaton, Bernie Armstead, and Pete Elliott. And, at the other extreme, Army officers attached to college faculties as professors of military science bear such names as Col. Nuñez C. Pilet, Col. Chester Arthur Rowland, Lt. Col. Converse Rising Lewis, and Maj. Elton Lacroix Titus.

An incidental, perhaps minor, corollary to Axiom II seems to be that the fancier the unusual name, the more likely it is that its possessor will be found teaching drama or art: witness Altinas Tullis, Dallas Draper, Dallas Williams, Chrystabelle Bryan Kisner, Burnice Myrick, and Michael Angelo McDowell, Jr. (Here I must admit that an admired and respected teacher of drama at my own undergraduate college bore the down-to-earth name of Alice Howell; and my most recently discovered male person with the given name of Dallas is a psychiatrist.)

While I was preparing the preceding notes for a meeting of the American Name Society, I had a sudden wave of trepidation lest my 40-year crisscross samplings might somehow be outdated by more recent developments. Therefore, at the last minute, I worked through a random collection of 1960 college catalogues (carefully not duplicating any regions previously studied). The results were, as the researcher's cliché says, gratifying:

Julius Seelye Bixler, Sherwood Fiske Brown, Jo Ann Sosalla Butler, Harrison Vernon Chase, Maridell Conners, Hazen Alonzo Curtis, A. Gib DeBusk, Kemp Frederick Gillum, Weymouth Tyree Jordan, John Crawford Milton Grimm, Milton Embick Flower, Eugene Stallcup Lawler, Harrye Fleming Lewis, Zell Forrest Mabee, Clifford Hazeldine Osborne, Edward Reginald Howard Malpas (a professor of dramatic art), Delinda 
Roggensack, Wellington Amos Parlin, Glover Emerson Tully, and Haroldene Whitcomb. More recent catalogues (1961-1969) show not dissimilar name-patterns.

I should add here that in these later catalogues I found my first major anomalies since this study began some 20 years ago. The presence of one Jack Waldo Eichinger is mildly puzzling, unless, of course, the "Waldo" was his "conditioning factor"; and one Glynise Smith taught, or teaches, not drama, as one might expect, but physical education.

Any such study, without a Carnegie grant and a research staff, must obviously remain inconclusive, perhaps never capable of anything like full proof. For one thing, as Elsdon C. Smith has pointed out, many people are, reluctant to discuss such personal matters as how - or whether - their names may have influenced their characters, thence their careers; for another, they just may not know. Another handicap is that the more recent listings tend increasingly to run more to middle initials than to full middle names. This could represent some subtle sociological change, a drift away from the ubiquitous American use of middle names; but, more likely, it may represent nothing more than sharply increased printing costs. Either way, however, this development somewhat reduces the value of these handiest sources of printed information.

On the other hand, plenty of partial evidence lies all about. When I delivered an early version of this paper at a meeting, one of my auditors, whom I had known since college days, rose to ask: "If your theory is sound, why are not my brothers and sisters all professors?" "That," I said, "is a good question; I'm glad you asked!" Thereupon, not without a mild gloat, I pointed out that his elder brother, bearing the not-usual given name of "Thomas Hobbes," was at that moment not only a professor but a department head and a dean; my questioner, named "Wilfrid" (note that $i$ spelling), was an editor of college textbooks, virtually a professor at one remove; and his two younger brothers, with not-usual name combinations, were, respectively, a highly specialized scientific draftsman and an artist. His two sisters did not count, because they had been given "ordinary" female names. In other words, of six children, the four with names falling into my "academic" category were all engaged in "literate," if not necessarily strictly literary, occupations.

To anticipate one question which often has come up, I must add that this theory has no bearing whatever on British or Canadian given names - probably because of more conservative tendencies in British family tradition.

Gaffney's Law suggests two tentative rules for parents:

1. If you want your child to have the best chance of becoming an athletic coach, or an Army officer (especially if he is drafted), give him an extroverted name, such as Harry, Jack, Joe, or Tom. (On the other 
hand, if you want to help him reach staff level, by way of West Point, give him a professorial-type name; consider Dwight David Eisenhower and Lucius Dubignon Clay.)

2. If you want him to become a professor (or a writer, or an editor), give him one of the less usual names - for example, Wilfrid, Eustace, or Kenneth. (For whatever reason, a surprising number of professors seem to be named Kenneth.) Better still, give him a pair of non-usual names: Gordon Laten, Severance Rodger (note that spelling), or Delbert Ferrell (and note that spelling). If you want him (or, more likely, her) to be an artist, or to teach fine arts, provide an artistic-type name such as Ariadne Diana or Minella Clairene.

Here, however, I must add an important warning: The name is in itself the guiding factor, and the child should not be pushed toward living up to it. I have in my files several accounts of disasters (at least from the parents' point of view) caused by attempts to push. The most striking example is that of a boy whose ambitious mother named him Ricardo Sebastian (for Bach) Taylor and then drove him through 12 mortal years of violin lessons. A dutiful lad, he took no action until his twenty-first birthday. Then, with a cooperative uncle, he sent down to the courthouse and had his name legally changed to Dick Taylor. And then he went home and called his mother into the parlor, where, calmly, without speechifying or visible rancor, he smashed his violin across his knee and departed to become an engineer. Today he builds, I am told, successful and profitable bridges, as head of his own firm.

If you are already adult, and would like to change your character, and thereby change your occupation, by changing your name to one of an opposite type, I am afraid that I cannot offer much encouragement. Astrologers, numerologists, and other mystics and near-mystics have long argued that a person's name influences his personality and so have worked out a variety of elaborate systems for switching to more desirable names. But it is probably not that simple. Some psychologists believe that one's character (and, by Gaffney's Law, therefore one's ultimate occupation) is fully determined by the age of 12 . So, to have your character and occupation influenced by your appelleation, you have no choice but just to grow up with the name.

The First Law of Nomenclature covers, in its present state, only two relative extremes, the men of action and the men of thought. That division leaves the vast middle marches of mankind unaccounted for; but if further and more scientific analysis - perhaps with that Carnegie grant I have mentioned, and with the aid of computers - could prove the total validity of the First Law and remove it from the realm of theory, it might then not be unlikely that, in the long run, we could assert with confidence that a man becomes a bricklayer because he is named John, or a druggist 
because he is named George. The possibilities are infinite, the evidence perhaps hard to get. Nevertheless, it is something to think about in the long winter evenings.

Over the years since I first voiced this theory, a good many people have asked me how and why I happened to get so deeply involved with it. "Elementary, my dear Watson!" I am a professor, and my name is

- Wilbur Geoffrey Gaffney.

University of Nebraska

\section{NAMES INSTITUTE}

Members of the American Name Society and other interested persons are invited to attend the Tenth Annual Names Institute on Saturday, May 1, 1971 in the auditorium of the New York Cultural Center. All linguists, specialists in onomastics and students in related fields are urged to attend the meeting which will be sponsored by the FlorhamMadison campus of Fairleigh Dickinson University. 